\title{
Civil Non-State Actors in Peacekeeping and Peacebuilding in West Africa
}

\author{
Abu Bakarr Bah* \\ Associate Professor \\ Department of Sociology \\ Northern Illinois University \\ DeKalb, IL 60115, USA \\ USA \\ abah@niu.edu
}

\begin{abstract}
This paper advances the notion of civil non-state actors in peacekeeping and peacebuilding. Using Sierra Leone, Liberia, and Côte d'Ivoire as cases studies, the paper identifies three kinds of civil non-state actors in war-torn countries: international non-governmental organizations (NGOs), community-based NGOs, and ad hoc community organizations. In addition, it argues that civil non-state actors play a critical problem-solving role in peacekeeping and peacebuilding and complement the role of state actors. The paper examines the role of civil non-state actors through their dialectical affinity with state actors in the peacekeeping and peacebuilding processes. It further expands the notion of non-state actors in peacekeeping and peacebuilding to encompass community-based NGOs and ad hoc community organizations. Moreover, it points to the positive role of civil non-state actors and the wide range of activities they perform, especially in peace mediation and postwar reconstruction.
\end{abstract}

Keywords

non-state actors; civil non-state actors; peacekeeping; peacebuilding; West Africa

\footnotetext{
* Abu Bakarr Bah is Associate Professor of Sociology at Northern Illinois University and Editor-in-Chief of the African Conflict \& Peacebuilding Review. He is also Faculty Associate at the Center for NGO Leadership and Development. He is the author of Breakdown and Reconstitution: Democracy, the Nation-State, and Ethnicity in Nigeria, and numerous articles in journals such as Critical Sociology, African Affairs, and International Journal of Politics, Culture, and Society. His current research is on civil wars and state-building in West Africa.
} 


\section{Introduction}

International peacekeeping has largely been associated with states, most notably the major world powers and regional powers. ${ }^{1}$ This perception of international peacekeeping as being primarily a state action stems from the fact that the legal and military actions that underpin peacekeeping operations are undertaken by states - either unilaterally, as part of a coalition, or through intergovernmental organizations such as the United Nations (UN), the African Union (AU), the Economic Community of West African States (ECOWAS), or the North Atlantic Treaty Organization (NATO). By the very nature of civil wars, clear categories of involvement (government forces, armed opposition, mercenaries, foreign troops, perpetrators of war crimes, victims, multinational corporations, etc.) emerge in the course of the violence. ${ }^{2}$ While each of the categories can be lumped into what is generally referred to as state actors, non-state actors and victims, such a distinction does not provide sufficient clarity for examining the peacekeeping dimension of civil wars. Peacekeeping and its concomitant peacebuilding process involve many actors whose roles are often not well-defined. Such actors include not only states and intergovernmental organizations, but also nongovernmental organizations (NGOs), statesmen, and community and national leaders, who seek to alleviate humanitarian crisis, end the fighting, peacefully resolve the conflict, or address the root causes of war. $^{3}$ This

1) Nicholas Wheeler, Saving Strangers: Humanitarian Intervention in International Society (Oxford: Oxford University Press, 200o); Adekeye Adebajo, Building Peace in West Africa: Liberia, Sierra Leone, and Guinea-Bissau (Boulder: Lynne Rienner Publishers, 2002); Ademola Adeleke, 'The Politics and Diplomacy of Peacekeeping in West Africa: The ECOWAS Operation in Liberia', Journal of Modern African Studies, vol. 33, no. 4, 1995, pp. 569-593; Adam Roberts, 'The Road to Hell: A Critique of Humanitarian Intervention', Harvard International Review, vol. 16, no. 1, 1993, pp. 10-14.

2) Mary Kaldor, New \& Old Wars: Organized Violence in a Global Era (Stanford: Stanford University Press, 2007); Roberta Cohen and Francis Deng, Masses in Flight: The Global Crisis of Internal Displacement, (Washington: Brookings Institution Press, 1998); Sara Meger, 'Rape in Contemporary Warfare: The Role of Globalization in Wartime Sexual Violence', African Conflict \& Peacebuilding Review, vol. 1, no. 1, 2011, pp. 100-132.

3) Kendall Stiles, 'Grassroots Empowerment: States, Non-State Actors and Global Policy Formulation', in Richard Higgott et al. (eds.), Non-State Actors and Authority in the Global System (London: Routledge, 200o), pp. 32-47; Mark Duffield, Global Governance and the New Wars: The Merging of Development and Security (London: Zed Books, 2001); Tanja Schümer, New Humanitarianism: Britain and Sierra Leone, 1997-2003 (Basingstoke: Palgrave Macmillan, 2008); Henry Carey, Privatizing the Democratic Peace: Policy Dilemmas of NGO Peacebuilding 
patchwork of actors produces the bifurcated categories of state and nonstate actors in peacekeeping and its associated peacebuilding process. While the category of state actors refers to states and intergovernmental organizations, the category of non-state actors tends to be a generalization for international NGOs and civil society.

Though the category of non-state actors is loose, it is often juxtaposed with the category of state actors in both the broader literature on security and the specialized works on peacekeeping and peacebuilding. ${ }^{4}$ This dichotomy between state actors and non-state actors raises important questions in international peacekeeping and peacebuilding. What constitutes non-state actors in peacekeeping and peacebuilding and what role do they play? How do state actors and non-state actors complement one another? What impacts do non-state actors have on peacekeeping and peacebuilding? While the role of state actors and their positions are often specified in the relevant resolutions and official policies that define peace operations' mandates, the roles of non-state actors tend to be ad hoc and constantly adapting to the pace of conflict and the deficit of appropriate state action. By addressing these questions, the study not only conceptualizes the notions of non-state actors in peacekeeping and peacebuiding, but also shows the range of non-state actors, the activities they perform, and how they can be better integrated into peacekeeping and peacebuilding processes and maximize their potential positive contributions.

In this study, non-state actors involved in peacekeeping and peacebuilding are referred to as civil non-state actors. The study argues that civil non-state actors in peacekeeping and peacebuilding, in contrast to other non-state actors, are domestic and global civil society bodies that play critical problem-solving roles at the local and national levels to advance human security and human development in war-torn countries. Moreover, the study argues that civil non-state actors complement the work of state actors by providing critical links to local actors and delivering vital services to war-affected populations without which state actors could not accomplish their missions. However, this complementarity is shaped by a dialectical tension between state actors and civil non-state actors that is rooted in

(Basingstoke: Palgrave Macmillan, 2012); Mark Schuller, Killing With Kindness: Haiti, International Aid, and NGOs (New Brunswick: Rutgers University Press, 2012).

4) See Diane E. Davis, 'Non-State Armed Actors, New Imagined Communities, and Shifting Patterns of Sovereignty and Insecurity in the Modern World', Contemporary Security Policy, vol. 30, no. 2, 2009, pp. 221-245; Claudia Hofmann 'Engaging Non-State Armed Groups in Humanitarian Action', International Peacekeeping, vol. 13, no.3, 2006, pp. 396-409. 
their different sources of power, nuanced understandings of core security and human rights values, and divergent interests. Though state and civil non-state actors are fundamentally different, they often share enough common interests to make them partners in peacekeeping and peacebuilding. Consequently, international peacekeeping has become an arena where states and civil non-state actors work along one another to promote shared security and humanitarian values, while maintaining their distinctive identity and moral boundaries. Furthermore, this complementarity simultaneously advances humanitarianism's goal of enhancing human security and human development and reinforces the dominance of a Northern agenda and the associated neo-imperialist liberal peace model. ${ }^{5}$

This article is based on research conducted at the UN in New York and in West Africa as part of a broader research project on international statebuilding in Sierra Leone, Liberia, and Côte d'Ivoire. ${ }^{6}$ In 2005, I conducted research at the UN Library and interviewed thirteen respondents working at the UN in New York. In 2008, I conducted field research in Sierra Leone, Liberia, and Côte d'Ivoire. I interviewed twenty-three respondents in Sierra Leone, seventeen in Liberia, and fifteen in Côte d'Ivoire. In 2012, I conducted field research in Senegal and interviewed twenty-one respondents. The respondents included diplomats, UN officials, NGO officials, government officials, officials of opposition political parties, and community leaders. Respondents were given consent forms and the options of maintaining complete or partial anonymity. Many respondents, especially diplomats, chose to remain anonymous.

\section{The Variety of Non-State Actors and Their Dialectical Affinity with State Actors}

In his study of climate change, Peter Newell used the terms non-governmental and non-state actors interchangeably to 'refer to actors that are not officially part of national government. ${ }^{7}$ However, this definition does not

5) Duffield, Global Governance and the New Wars; Schuller, Killing With Kindness.

6) The research on international state-building started in 2005 with funding from the West African Research Association. Additional funding has been provided by Northern Illinois University and the Council of American Overseas Research Centers.

7) Peter Newell, Climate for Change: Non-State Actors and the Global Politics of the Greenhouse (Cambridge University Press, 2000), p. 1. 
distinguish non-state actors involved in waging war from those involved in peacekeeping and peacebuilding. In terms of waging wars, non-state actors include the armed opposition and transnational corporations and networks involved in fighting, as well as in illicit trade of arms, minerals, and drugs. ${ }^{8}$ In the context of peacekeeping and peacebuilding, non-state actors largely refer to international NGOs working to provide humanitarian relief and promote post-war reconstruction. ${ }^{9}$ This ambiguity of what constitutes non-state actors persists in the literature on security, civil society and development. The most vivid distinction in the literature is between armed nonstate actors waging wars and unarmed non-state actors working as civil society organizations. While the notion of armed non-state actors is well developed, there are critical gaps in conceptualizing civil (i.e. unarmed) non-state actors. Civil non-state actors in peacekeeping and peacebuilding have been largely reduced to international NGOs.

In her critique of sovereignty and security in the globalized world, Diane Davis identified a wide range of armed non-state actors who directly challenge state authority, tacitly undermine state authority, or clandestinely work for the state. ${ }^{10}$ They range from armed political movements seeking regime change to transnational criminal rings, community-based vigilantes, and armed private security contractors. Davis argues that the variety of armed non-state actors not only challenges the "greed versus grievance" dichotomy, but also 'signals the widespread transfer of security functions from the state to civil society.'11 In South-Eastern Afghanistan, for example, non-state actors filled the vacuum of state authority by performing community policing functions. The non-state actors included strongmen militia, criminal networks, private security contractors, Taliban insurgents, terrorist groups, and tribal police. ${ }^{12}$ One set of armed non-state actors that

\footnotetext{
8) Davis, 'Non-State Armed Actors, New Imagined Communities, and Shifting Patterns of Sovereignty and Insecurity in the Modern World'; Benedict Kingsbury, 'Claims by Non-State Groups in International Law', Cornell International Law Journal, vol. 25, no. 3, 1992, pp. 481-513.

9) Carey, Privatizing the Democratic Peace; Hofmann 'Engaging Non-State Armed Groups in Humanitarian Action'.

10) Davis, 'Non-State Armed Actors, New Imagined Communities, and Shifting Patterns of Sovereignty and Insecurity in the Modern World'.

11) Ibid., p. 223 .

12) Susanne Schmeidl and Masood Karokhail, "The Role of Non-State Actors in "CommunityBased Policing" - An Exploration of the Arbakai (Tribal Police) in South-Eastern Afghanistan', Contemporary Security Policy, vol. 30, no. 2, 2009, pp. 318-342.
} 
has featured prominently in the peace and conflict literature are liberation and separatist movements. Such groups have increased in prominence to the point that their claims and relations to states is the subject of significant debates in international law. Benedict Kingsbury identified three general domains that are critical to the claims of liberation and separatist movements and their relation to states. These are self-determination, minority rights, and human rights. ${ }^{13}$ Using the Kosovar Albanians and the Armenians of Nagorno-Karabakh separatist movements as case studies, Anne-Marie Gardner argues that 'the international community assesses a claimant group's capacity for liberal democratic governance as a means to evaluating the group's self-determination claim.'14 The issues of human rights and democratic practices point not only to the attempt to socialize armed non-state actors into international human rights norms, but also their dialectical relation to states. This dialectical relation is manifested in the friction between liberation and separatist movements' claims to human rights and democracy and states' efforts to hold them accountable for human rights and democracy. As Davis also notes, the relation between states and armed non-state actors is complicated by the issue of sovereignty. ${ }^{15}$ In some cases, states see armed non-state actors as a threat to authority, while in other cases they call upon armed non-state actors to help them reinforce and exert state authority.

Most of the civil society and development literature focuses on civil nonstate actors, especially international NGOs. ${ }^{16}$ As with armed non-state actors, civil non-state actors include a variety of organizations that are not entirely separated from the state. Moreover, civil non-state actors may include groups that do not neatly fall within the domain of civil society. Henry Carey argues that 'The narrow view of NGOs holds that they only represent non-profit, service, and advocacy organizations in public affairs. Non-state actors (e.g., for-profit corporations or non-profit trade associations) and nationalist groups (e.g., violent terrorists and revolutionary cells) are excluded from this definition. An opposite conception of NGOs includes any association, liberal and civil or illiberal and uncivil, that is not part of

13) Kingsbury, 'Claims by Non-State Groups in International Law'.

14) Annemarie Gardner, 'Beyond Standards before Status: Democratic Governance and Non-State Actors', Review of International Studies, vol. 34, no. 3, 2008, pp. 531, 552, p. 534.

15) Davis, 'Non-State Armed Actors, New Imagined Communities, and Shifting Patterns of Sovereignty and Insecurity in the Modern World'.

16) Schuller, Killing With Kindness; Hofmann, 'Engaging Non-State Armed Groups in Humanitarian Action'; Carey, Privatizing the Democratic Peace. 
the government but influences society (excludes states and parties). ${ }^{17}$ Carey's narrow view restricts the definition of non-state actors to NGOs that work within the realm of civil society to promote human rights and human development. Similarly, in this study we use the term civil non-state actors to refer to NGOs and ad hoc community organizations working to build peace in war-torn countries.

As with armed non-state actors, civil non-state actors have a dialectical relation with state actors. Civil non-state actors often find themselves dependent on states, while trying to maintain their autonomy and hold states accountable. Kendall Stiles captured this paradox in his notion of civil society empowerment, which brings together state and non-state actors in a way that seeks to move from state-centered development to citizen participation. ${ }^{18}$ The key players in civil society empowerment are donor states, developing states, multilateral donor organizations, NGOs, and grassroots organizations. Mark Schuller presents a cynical view of this paradox through his notion of trickle-down imperialism. He sees NGOs as "semi-elites" who have inherited past world systems and pillars of contemporary globalization by ' $[\mathrm{m}]$ ediating contacts between Northern donors and agencies and local communities in the South. ${ }^{19}$ In contrast, Claudia Hofmann presents a positive angle to NGOs in peacekeeping and peacebuilding; albeit it is limited to the sphere of human rights. ${ }^{20}$ She examines the way state actors and two international NGOs (i.e. Geneva Call and Save the Children-UK) engaged armed groups in the Democratic Republic of Congo (DRC), Colombia, Sri Lanka, Sudan, and Liberia to combat the use of child soldiers and anti-personnel landmines. Hofmann argues that 'nongovernmental organizations offer the potential to fill the gap in the international legal regime by employing lower-key initiatives that avoid political issues such as the legitimization or recognition of non-state armed groups.' ${ }^{21}$ She sees international NGOs as uniquely positioned to complement the work of state actors by using a "soft approach" that is more oriented toward problem-solving and policy.

Hofmann makes two important contributions that are relevant for this study. First, her work underscores the civil and positive role of non-state

\footnotetext{
17) Carey, Privatizing the Democratic Peace, p. 10.

18) Stiles, 'Grassroots Empowerment'.

19) Schuller, Killing With Kindness, p. 179.

20) Hofmann, 'Engaging Non-State Armed Groups in Humanitarian Action'.

21) Ibid., p. 396.
} 
actors in peacekeeping and peacebuilding. Second, she sees the relation between non-state and state actors as a healthy collaboration that promotes peace and protects civilians. Her work departs from both the armed non-state actors and the cynical civil non-state actors studies. Like many of the studies, however, Hofmann also reduces civil non-state actors in peacekeeping and peacebuilding to international NGOs. ${ }^{22}$ This study expands her work in two ways. First, it examines the role of civil non-state actors in other areas of peacekeeping and peacebuilding, most notably peace negotiations and delivery of services. Second, it identifies two other civil non-state actors (i.e. community-based NGOs and ad hoc community organizations ), in addition to international NGOs.

\section{Variety of Civil Non-State Actors}

The peacekeeping and peacebuilding processes in Sierra Leone, Liberia, and Côte d'Ivoire reveal three kinds of civil non-state actors that perform a wide range of activities to promote human security and human development in war-torn countries: international NGOs, community-based NGOs, and ad hoc community organizations.

International NGOs are transnational corporate civil society organizations with a clearly defined mission, in most cases aimed at enhancing human security and human development. Their mission can focus on all persons - with organizations such as the International Committee of the Red Cross (ICRC) or Médecins Sans Frontières (MSF) - or a particular demographic group - with organizations such as Save the Children. The defining features of these kinds of civil non-state actors are their transnational and corporate characters. As Krishna Kumar notes, corporate NGOs have large annual budgets, and managerial practices that are closer to corporations than to voluntary organisations. This [...] kind of NGOs openly competes with the state and frequently asserts that the latter is redundant, so it might as well reconcile to handing over its responsibilities, especially those pertaining to the education and health of the poor. ${ }^{23}$ Sangeeta Kamat refers to these kinds of civil non-state actors as advocacy NGOs. As she notes, 'Advocacy NGOs do not operate locally, that is, they do not represent a particular geographically defined community. Rather they tend to be issue

\footnotetext{
22) Hofmann, 'Engaging Non-State Armed Groups in Humanitarian Action'.

23) Krishna Kumar, 'Partners in Education', Economic and Political Weekly, vol. 43, no. 3, 2008, p. 9.
} 
based and the constituency they represent may encompass different regions and countries. [...] Also, in comparison to [community-based organisations] CBOs, advocacy NGOs are better funded, professionally staffed and are housed in metropolitan centres such as Washington DC or New Delhi.'24

Community-based NGOs are registered civil society organizations with a clearly stated mission to promote human security and human development and a formal leadership and management structure. In contrast to international NGOs, community-based NGOs operate at the local or national levels. Moreover, they are small both in terms of budget and staff. Such organizations include Campaign for Good Governance (CGG) in Sierra Leone, Ligue Ivoirienne des Droits de l'Homme (LIDH), and the Liberian Council of Churches (LCC). While community-based NGOs have missions and stated objectives, they are mostly defined by the activities they carry out. As such, community-based NGOs typically have a membership base and clear beneficiary group who actively participate in their activities. As Kamat argues, community-based NGOs 'interact with their membership base on a daily basis, to build relations of cooperation and trust with them, to understand their needs and plan projects that respond to these needs. Consequently, CBOs tend to have close and intimate working relations with men and women of the community and local leaders, some of whom may also work as paid staff for the NGO.25 However, community-based NGOs typically depend on international NGOs, foreign governments, and national governments for funding. Most of their funding comes in the form of contracts and grants to implement specific projects to enhance human development. As the CGG states, for example, the organization 'works with key partners including international NGOs and government departments such as the police to effectively deliver programs [...] and is funded extensively by a number of international bodies. ${ }^{26}$

Ad hoc community organizations are informal groups established by local or national leaders to address a specific urgent problem within a community or the country at large. Their membership tends to be selective, but fairly representative of the collective will of the people. They are temporary

\footnotetext{
24) Sangeeta Kamat, 'The Privatization of Public Interest: Theorizing NGO Discourse in a Neoliberal Era', Review of International Political Economy, vol. 11, no. 1, 2004, p. 161.

25) Kamat, 'The Privatization of Public Interest', pp. 159-160.

26) Campaign for Good Governance Organizational Profile, http://www.slcgg.org/aboutCGG .html, accessed 14 September 2012.
} 
bodies that may or may not evolve into a community-based NGO. Ad hoc community organizations engage in troubleshooting rather than program implementation. They rely heavily on the cultural and social capital of the members to accomplish their tasks. While most ad hoc community organizations are established to address local problems (sanitation, family feuds, water management, etc.) there are a few that address national issues. Ad hoc community organizations at the national level tend to emerge during times of major national crisis such as civil war. National ad hoc community organizations such as the Inter-Religious Council and the Mano River Women Peace Network (MARWOPNET) were pivotal in helping negotiate peace agreements in Sierra Leone and Liberia. ${ }^{27}$ At the local level, ad hoc community organizations have also been critical in helping peacekeepers and humanitarian aid workers negotiate with low-ranking battlefield commanders who control critical access roads to civilians trapped by fighting. While ad hoc community organizations operating at the village and town levels may not have direct impacts on peace mediation, they provide critical help to peacekeepers and humanitarian workers on the ground. ${ }^{28}$

\section{Civil Non-State Actors in Sierra Leone, Liberia, and Côte d'Ivoire}

All three types of civil non-state actors played a significant role in the peacekeeping and peacebuilding efforts in Sierra Leone, Liberia, and Côte d'Ivoire. A search of four international databases and directories of NGOs and one national directory for Sierra Leone and Liberia revealed the existence of over 630 NGOs in Sierra Leone, Liberia, and Côte d'Ivoire. Collectively, the databases and directories listed 300 NGOs in Sierra Leone, 154 in Liberia and 180 in Côte d'Ivoire. ${ }^{29}$ The organizations listed include

27) Interview, reverend, Freetown, 25 June 2008; interview, Muslim cleric, Monrovia, 1 June 2008; interview, reverend, Monrovia, 2 June 2008; interview, female politician, Monrovia, 3 June 2008; interview, female MARWOPNET leader, Freetown, 2 July 2008.

28) Stefan Sperl and Machtelt De Vriese, From Emergency Evacuation to Community Empowerment: Review of the Repatriation and Reintegration Programme in Sierra Leone (EPAU/2005/or) (Geneva: UNHCR, February 2005).

29) Directory of Development Organizations [http://www.devdir.org/africa.htm], accessed 11 August 2012; NGO Branch, UN Department of Economic and Social Affairs, [http://www .un.org/africa/osaa/ngodirectory/index.htm], accessed 12 September 2012; UNODC [http:// www.unodc.org/ngo/showExtendedSearch.do], accessed 2 August 2012; Worldwide NGO Directory, [http://www.wango.org/resources.aspx?section=ngodir\&sub=region\&regionID $=11 \&$ col=ffccoo], accessed 5 September 2012; Liberia NGO Directory, [http://www.cental.org/ index.php?option=com_sobi2\&Itemid=76], accessed 8 September 2012; List of Charities and 
major international NGOs such as ICRC, MSF, Amnesty International, and the Norwegian Refugee Council. There was also a wide array of communitybased NGOs such as CGG, Fifty-Fifty Group, and National Forum for Human Rights in Sierra Leone. In Liberia, the community-based NGOs included the Interfaith Council of Liberia and LCC. Some of the notable communitybased NGOs in Côte d'Ivoire include the Forum of African Civil Society for Sustainable Development, the Collective of Civil Society for Peace, and LIDH. Many of the community-based NGOs in all three countries emerged during the civil war periods. While some of the international NGOs had presence in all three countries before the outbreak of the civil wars, international NGOs also became heavily involved in these countries during the civil wars. ${ }^{30}$ The databases clearly delineated international NGOs from community-based NGOs. Though the databases and directories seem exhaustive, they mostly list formally registered organizations which suggest that ad hoc community organizations that emerged during the war periods were not listed unless they later became NGOs.

Field research in Sierra Leone, Liberia, and Côte d'Ivoire also revealed the existence of important ad hoc community organizations that emerged during the civil wars. These organizations include high profile ad hoc committees of religious and national elders and women's groups that played critical roles in facilitating peace negotiations between the governments and opposition forces. Though most of these were temporary and informal bodies, they played critical roles in facilitating peacekeeping. Some of the most notable ad hoc community organizations include the Inter-Religious Council in Sierra Leone, the Collective of Religious Confessions for National Reconciliation and Peace in Côte d'Ivoire, the Inter-Religious Council in Liberia, and MARWOPNET.

\section{Dialectical Affinity between Civil Non-State Actors and State Actors}

As both the armed non-state actors and civil non-state actors literature show, non-state and state actors are dialectically connected. A proper concept of civil non-state actors requires not only expanding the notion from international NGOs to encompass community-based NGOs and ad hoc

NGOs in Sierra Leone, [http://all-sierra-leone-information.2284971.n4.nabble.com/Charities -and-NGOs-in-Sierra-Leone-f3357059.html], accessed 3 September 2012.

30) Interview, MSF official, New York, 5 July 2005; interview, UNDP official, Freetown, 1 July 2008. 
community organizations, but also examining the complementarity and contradictions between civil non-state actors and state actors. This dialectical affinity is largely tied to the differences and similarities in the mandates, values, and interests of state actors and civil non-state actors.

In terms of mandate, civil non-state actors are fundamentally different from state actors. This stems from the fact that states are sovereign entities within the international system with the responsibility to maintain order within their boundaries and the right to protect themselves against external threats. ${ }^{31}$ This sovereignty is only tempered with the obligations to respect the sovereignty of other states and international conventions and accept international humanitarian intervention in cases of extraordinary situations that significantly undermine human security and regional or world peace. ${ }^{32}$ In the context of peacekeeping, state actors acquire the authority to exert power over people in a war-torn country as defined by the mandate given to them by the states or intergovernmental organization they represent. Such powers can include the right to control the movement of people and goods, detain people, and use force. In Sierra Leone, for example, UN Security Council resolution 1289 of February 2000 empowered peacekeepers to provide security and control the flow of people and goods. In Liberia, UN peacekeepers were empowered 'to apprehend and detain former President Charles Taylor in the event of a return to Liberia and to transfer him or facilitate his transfer to Sierra Leone for prosecution before the Special Court for Sierra Leone and to keep the Liberian Government, the Sierra Leonean Government and the Council fully informed. ${ }^{33}$ In addition to their mandates, state actors, especially major countries, can deploy significant financial and military resources to increase their powers.

In contrast, civil non-state actors are voluntary bodies that operate within the global and domestic civil society domain. They have no jurisdiction over the people they seek to help. However, civil non-state actors possess financial, moral, and social capital which gives them a significant

31) Hans Gerth and C. Wright, From Max Weber: Essays in Sociology (New York: Oxford University Press, 1946); Charles Tilly, 'Reflections on the History of European State-Making', in Charles Tilly (ed.), The Formation of National States in Western Europe (Princeton, N.J.: Princeton University Press, 1975), pp. 3-83.

32) ICISS, The Responsibility to Protect: Report of the International Commission on Intervention and State Sovereignty (Ottawa, Canada: International Development Research Centre, 2001); Kofi Annan, 'Two Concepts of Sovereignty', The Economist, vol. 352, no. 8137, 1999, pp. 49-50; Commission on Human Security, Human Security Now (New York: United Nations, 2003); Thomas Weiss, Humanitarian Intervention: Ideas in Action (Cambridge: Polity Press, 2007).

33) UN Security Council, Resolution 1638, 11 November 2005. 
amount of influence in war-torn countries. ${ }^{34}$ By controlling the distribution of food and medicine, for example, international NGOs exerted influence on the movement of people in Sierra Leone and Liberia. NGOs can also shame people suspected of war crimes or impeding peace and thereby force state actors to place them under international sanctions (travel bans, freezing assets, etc.) or indict them for war crimes. ${ }^{35}$ This is clearly the case in Sierra Leone and Liberia where a virtual consensus developed in the civil society community that Foday Sankoh, leader of the Revolutionary United Front (RUF), and former Liberian president Charles Taylor were impeding peace. ${ }^{36}$ Both of these men were placed under international sanctions and ultimately arrested for war crimes. Such actions could have hardly occurred without the moral support of civil non-state actors. Though state and civil non-state actors have different claims to authority, they both have some power in affecting conditions in war-torn countries. States have political and military power, while civil non-state actors possess deep cultural and social capitals, which are needed to effect humanitarian relief and move peace processes forward. The emotional pressure women's groups exerted on warlords during the 2003 Liberian peace talks in Accra is an example of the cultural capital of civil non-state actors. Because state and civil nonstate actors tend to bring different kinds of capital and power in peacekeeping and peacebuilding, they often work in partnership to promote shared humanitarian objectives. ${ }^{37}$

In terms of values, state and civil non-state actors often refer to common notions of security, human rights, and democracy. States, especially Western powers, see these values as part of their democratic political culture and international human rights conventions. Similarly, NGOs have missions which are predicated on peace, democracy, and human rights. However, state and civil non-state actors have nuanced understandings of these common values and pursue them according to their own interests. States have typically approached international peacekeeping and peacebuilding from the perspective of regional and international security and compliance with international norms on democratic governance and human rights. ${ }^{38}$ These values are interpreted in-line with historical and ideological ties and

\footnotetext{
34) Duffield, Global Governance and the New Wars; Schuller, Killing With Kindness.

35) Interview, International Crisis Group official, Dakar, 3 July 2012; interview, African diplomat, Dakar, 2 July 2012.

36) This view was expressed by numerous respondents during the interviews I conducted in New York, Liberia, Sierra Leone, and Senegal.

37) Hofmann, 'Engaging Non-State Armed Groups in Humanitarian Action'.

38) Interview, military leader and diplomat, Dakar, 6 July 2012.
} 
strategic economic and political interests. States have consistently tied peacekeeping operations to the need to maintain regional security and implement multiparty elections. In all three West African cases, the ECOWAS and UN peacekeeping missions were largely seen as ways to maintain security in a region that was experiencing growing political turmoil. The ECOWAS intervention in Liberia in 1990 was initiated by Nigeria as soon as the war began in part because Nigerian dictator Ibrahim Babangida saw the civil war as a security threat to dictatorial regimes in the region. ${ }^{39}$ In Côte d'Ivoire too, the 2003 ECOWAS intervention was largely driven by the desire to halt the growing regional insecurity. Similarly, the peacekeeping operations in these countries were anchored in the efforts to join the democracy bandwagon. In Sierra Leone, for example, Nigerian dictator Sani Abacha became a staunch supporter of the military intervention to restore the democratically elected president, Ahmed Tejan Kabbah, ousted from power by the military and rebel forces in 1997. Though Abacha was suppressing democracy at home, Sierra Leone became an opportunity for him to present himself as a champion of democracy. Most importantly, the peacekeeping missions in all three countries were centred on multiparty elections as stipulated in the various peace agreements. ${ }^{40}$ The emphasis on multiparty elections dovetails with the international demand for democracy in Africa, which began in the early $1990 .^{41}$

In contrast to state actors' focus on regional security and democracy, civil non-state actors approach peacekeeping and peacebuilding from the much broader human security and human development perspectives instead of mere state or regional security. Civil non-state actors seek not only to promote democracy, but more importantly to provide humanitarian relief,

39) Adebajo, Building Peace in West Africa; Adeleke, 'The Politics and Diplomacy of Peacekeeping in West Africa'.

40) Abu Bakarr Bah, 'Democracy and Civil War: Citizenship and Peacemaking in Côte d'Ivoire', African Affairs, vol. 109, no. 437, 2010, pp. 597-615; Sierra Leone, Peace Agreement Between the Government of Sierra Leone and the Revolutionary United Front of Sierra Leone (Lomé, Togo, 7 July 1999); Liberia, Comprehensive Peace Agreement Between the Government of Liberia and the Liberians United for Reconciliation and Democracy (LURD) and the Movement for Democracy in Liberia (MODEL) and Political Parties (Accra, Ghana, 18 August 2003).

41) Abu Bakarr Bah, 'Changing World Order and the Future of Democracy in Sub-Saharan Africa', Proteus: A Journal of Ideas, vol. 21, no. 1, 2004, pp. 3-12; Michael Bratton and Nicolas Van de Walle, Democratic Experiments in Africa: Regime Transitions in Comparative Perspective (Cambridge: Cambridge University Press, 1997). 
prosecute human rights abuses and promote human development during the post-war period. ${ }^{42}$ They approach peacekeeping and peacebuilding more as a human security, rather than a state security issue. While states are wedded into the legal and security aspects of world order, civil nonstate actors champion humanism and social justice. These values are reflected in their missions and the kinds of activities they promote. The ICRC, for example, states that it 'is an impartial, neutral and independent organization whose exclusively humanitarian mission is to protect the lives and dignity of victims of armed conflict and other situations of violence and to provide them with assistance.' Moreover, 'the ICRC also endeavours to prevent suffering by promoting and strengthening humanitarian law and universal humanitarian principles. ${ }^{43}$ Though the plethora of civil non-state actors all tend to focus on a narrow aspect of political and social rights (refugees, health, women's rights, etc.), collectively their works span all dimensions of human security and human development.

Finally, both state and civil non-state actors have strategic interests that they must preserve as they engage in peacekeeping and peacebuilding. States have a clear self-interest in ensuring security within their territories. As such, any conflict that threatens their own internal order becomes a matter of significant interest to them. The most typical forms of security threats from war-torn countries are the flow of arms and combatants, state collapse and the possibility of creating safe havens for terrorists, and massive flow of refugees. ${ }^{44}$ Apart from security interests, states may have strategic economic and geopolitical interests in war-torn countries that they need to protect..$^{45}$ In each of the three countries under consideration, the former colonial power played major roles in the international interventions. Britain pushed for significant UN involvement and deployed troops

\footnotetext{
42) Interview, MSF official, New York, 5 July 2005; interview, UNDP official, Freetown, 1 July 2008; interview, International Crisis Group official, Dakar, 3 July 2012.

43) International Committee of the Red Cross, Mission, http://www.icrc.org/HOME.NSF/o6oa 34982cae624ec12566feoo326312/125ffe2d4c7f68acc1256ae300394f6e?OpenDocument, accessed 10 November 2012.

44) Interview, European diplomat, New York, 23 May 2005; interview, American diplomat, New York, 27 May 2005; interview, EU official, Abidjan, 10 July 2008.

45) Robert Aldrich, Greater France: A History of French Overseas Expansion (New York: St. Martin's Press, 1996); Padraig Carmody, The New Scramble for Africa (Cambridge: Polity Press, 2011); Andrew Dorman, Blair's Successful War: British Military Intervention in Sierra Leone (Farnham, England: Ashgate, 2009); Wayne Chatfield Taylor, The Firestone Operations in Liberia (Washington, D.C.: National Planning Association, 1956).
} 
in Sierra Leone in May 200o, while France did the same in Côte d'Ivoire. In November 2004 and early 2011, for example, French forces directly engaged in fighting with forces loyal to former president Laurent Gbagbo. In Liberia, the United States deployed troops in August 2003 to provide logistical support to ECOMOG and protect civilians during one of the most critical points in the peacekeeping operation.

Civil non-state actors too have strategic interests in the survival and growth of their organizations. As social entrepreneurs, NGOs must constantly raise money to cover their operational and program costs. NGOs not only seek to do good, but also to ensure their own material wellbeing by doing good. ${ }^{46}$ While doing good and living off good are not mutually exclusive, the symbiosis between the two leaves critical questions about the operations of civil non-state actors and their impact on peacekeeping and peacebuilding. Civil non-state actors have two mutually reinforcing interests. First is the need to be seen as doers of good. This not only provides a justification for their existence, but also provides an argument for continued financial support from donors. Second is the need to maintain operational capacity and growth of their organizations. This requires them to constantly seek funding from donors and undertake new projects. Peacekeeping and peacebuilding operations provide opportunities for NGOs to be seeing as doing good and grow. ${ }^{47}$

Notwithstanding their differences, state and civil non-state actors have overlapping features which draw them into peacekeeping and peacebuilding. They both have some common human rights and humanitarian values, strategic interests in peacekeeping and peacebuilding, and the ability to exert power in war-torn countries. These commonalities and divergences are manifested in a dialectical affinity that simultaneously requires collaboration and boundary maintenance.

Because of states' unique position of authority and ability to use military force, civil non-state actors sometimes need the support of state actors in order to broadly deliver humanitarian relief. This kind of collaboration is often manifested in efforts such as securing humanitarian corridors, escorting humanitarian convoys, guarding refugee camps, and protecting

46) Stephen Ndegwa, The Two Faces of Civil Society: NGOs and Politics in Africa (West Hartford: Kumarian Press, 1996); David Mosse, Cultivating Development: An Ethnography of Aid Policy and Practice (London: Pluto Press, 2005); Aiden Southall, 'Small Urban Centers in Rural Development: What Else is Development other than Helping your Own Home Town?' African Studies Review, vol. 31, no. 3, 1988, pp. 1-15; Schuller, Killing with Kindness.

47) Duffield, Global Governance and the New Wars; Schuller, Killing With Kindness. 
warehouses. ${ }^{48}$ Yet, this collaboration may also mask some of the differences between state and civil non-state actors in terms of treatment of civilians (especially women) and suspected combatants, priority places for providing humanitarian relief, target populations, and duration of operations. In a similar way, state actors often count on civil non-state actors in order to establish contacts with opposition combatants and commanders, overcome impasses in peace mediation, provide cultural knowledge and up-todate accounts of situations on the ground, and implement humanitarian relief projects. To the extent that state actors also see security in terms of human development, they often provide financial support to NGOs. For states, NGOs may provide a better alternative for channelling humanitarian assistance instead of handing over resources to governments which are either engaged in war, lack legitimacy, or incapable of effective implementations. Thus, while state actors enable civil non-state action, civil nonstate actors also facilitate the implementation of the missions and policies of state actors.

\section{Activities of Civil Non-State Actors in War-Torn Countries}

War-torn countries typically face three major challenges: alleviating humanitarian suffering, negotiating and implementing a durable peace agreement, and post-war reconstruction. ${ }^{49}$ State and civil non-state actors address these challenges by establishing peacekeeping missions, pursuing peace negotiations, and supporting post-war reconstruction programs. Civil non-state actors not only complemented the works of state actors, but they also played critical problem-solving roles that were vital for the peacekeeping and peacebuilding operations in Sierra Leone, Liberia and Côte d'Ivoire. The extant literature has not only failed to adequately conceptualize the variety of civil non-state actors, but it has also left out or undervalued some of their contributions to peacekeeping and peacebuilding. ${ }^{50}$

\footnotetext{
48) Interview, UNIOSIL official, Freetown, 26 June 2008; interview, former Senegalese military official and peacekeeper, Dakar, 18 June 2012.

49) Abu Bakarr Bah, 'The Contours of New Humanitarianism: War and Peacebuilding in Sierra Leone', Africa Today, vol. 6o, no. 1, 2013, pp. 3-26.

50) Hofmann, 'Engaging Non-State Armed Groups in Humanitarian Action'; Carey, Privatizing the Democratic Peace; Schuller, Killing With Kindness; Duffield, Global Governance and the New Wars.
} 
The first challenge of alleviating humanitarian suffering typically triggers peacekeeping operations. Peacekeeping includes both military and civilian activities aimed at creating conditions for delivering humanitarian assistance, protecting civilians, and implementing ceasefire or peace agreements. It revolves around formally established military and civilian operations, such as the ECOWAS Cease-Fire Monitoring Group (ECOMOG) in Liberia and Sierra Leone, the United Nations Mission in Sierra Leone (UNAMSIL), the United Nations Mission in Liberia (UNMIL), and the United Nations Operation in Côte d'Ivoire (UNOCI). Peacekeeping missions are internationally authorized military operations with defined political, security and humanitarian objectives undertaken by military personnel with the support of a more or less important professional civilian staff. While the security aspect of peacekeeping is exclusively undertaken by state actors (i.e. military and police forces), the humanitarian dimension of peacekeeping is undertaken by state actors (i.e. civilian staff of states and intergovernmental organizations) and civil non-state actors. Because of their access to resources and operational infrastructure, international NGOs have been the main civil non-state actors in the delivery of humanitarian relief and advocacy against war crimes. International NGOs often work with community-based NGOs and ad hoc community organizations at the local level to reach victims and provide critical supplies such as water, food and medicine. In Liberia and Sierra Leone, for example, MSF and the ICRC delivered huge supplies of medicines during the war, operated numerous mobile clinics, and provided critical services in public hospitals. Back in February and March 1998, MSF carried out 960 surgical interventions at Connaught hospital in Freetown. It also had a surgeon at Netlands hospital and provided basic health services for around 12,00o refuges at the national stadium in Freetown. In Kambia district, it deployed a medical team, which provided medical and nutritional services for approximately 15,000.51

The second challenge of negotiating and implementing a peace agreement is largely addressed through formal peace mediations led by stateactors. At the outset of civil wars, states and intergovernmental bodies initiate a mediation process to get the warring parties to resolve their differences peacefully. The scope and vigour of these mediation efforts largely depend on the intensity of the conflict and the extent to which other states,

51) Doctors without Borders, Sierra Leone: MSF Back in Freetown Hospitals, http:// www.doctorswithoutborders.org/press/release.cfm?id=469\&cat=press-release, accessed 7 September 2012. 
especially the major powers, are vested in the country. In Côte d'Ivoire, for example, France quickly initiated a peace process leading to the LinasMarcoussis Agreement in 2003. Though the agreement was fundamentally flawed, it is an example of quick action by a vested power. In Liberia and Sierra Leone, it took several years for the peace processes to really develop. Liberia signed its first substantive peace agreement in 1993 in Cotonou, while Sierra Leone reached its first agreement in 1996 in Abidjan. As all three countries show, state actors often find it difficult to resolve civil wars in a timely manner. Too often, the peace mediation processes drag on as violence escalates. Moreover, peace mediation processes are plagued by repeated violations and collapse of peace agreements and stalemates in negotiating new agreements. ${ }^{52}$

Though civil non-state actors are not formal members of the peace meditation processes, international NGOs and ad hoc community-based organizations play critical roles in establishing contacts with opposition fighters and diffusing stalemates in peace negotiations and implementation at both the national and battlefield levels. In Sierra Leone, for example, the ICRC made the first public radio contact with Sankoh, the RUF leader, and provided the helicopter that transported him from his base to Abidjan for the 1996 peace talks. ${ }^{53}$ Similarly, when RUF rebels abducted huge numbers of civilians and refused to negotiate during the January 1999 invasion of Freetown, ECOMOG resorted to religious leaders to help negotiate with rebel commanders for a ceasefire and the release of abducted civilians. At the request of the ECOMOG commander, the religious leaders went to the RUF base and convinced the commanders to release the abducted children. As one of the clergymen who participated in the negotiations recalled:

[...] the late Brigadier-General Maxwell Khobe [...] wanted to talk with the rebel commanders $[\ldots]$ we had a meeting with the rebels $[\ldots]$ they were able to release about thirty-two children they abducted in Freetown and on the way. They released them to me and I took them back to the ECOMOG checkpoint. And so I handed over those children. Then, I joined my colleagues into the bush and the large number of rebels. [...] We sat down and we talked. [...] they accepted that they had done some bad things and were willing to apologize to the people for their actions personally, to express their

52) Bah, 'Democracy and Civil War'; Adebajo, Building Peace in West Africa.

53) Krijn Peters, War and the Crisis of Youth in Sierra Leone (Cambridge: Cambridge University Press, 2011); Howard French, 'African Rebel with Room Service', New York Times, 23 June 1996, http://www.nytimes.com/1996/o6/23/world/african-rebel-with-room-service .html?pagewanted=all\&src=pm, accessed 4 October 2012. 
deepest regrets for what they have done, especially burning some of the strategic buildings in the city. ${ }^{54}$

The contacts between the religious leaders and the RUF rebels later evolved to include discussions with the RUF leader. They convinced Sankoh to agree to compressive peace talks. As the clergyman further stated, 'we went to President Kabbah and we told him [that Sankoh has agreed to holding peace talks]. [...] We convinced Foday Sankoh, out of the several meetings we had, for a roundtable peace talks. He accepted that. He convinced his commandos. The only problem that was a real issue was the venue [for the peace talks]. ${ }^{55}$

In Liberia an ad hoc group of women went to the 2003 Accra peace talks to pressure the warlords to reach a peace agreement, even though they were not invited to the talks. The women used cultural and psychological pressures to force the warlords to continue the negotiation until they ended the stalemate. As one female community leader recalled about the Accra peace talks:

We decided that we are not just going to stay in Liberia, but we'll send a delegation to Ghana; and that delegation went and mobilized Liberian women on the [refugee] camps - even women from the Northern region in Ghana joined the process and they were there mounting pressure [...]. In terms of negotiating or engaging with stakeholders, we told them what we wanted, for example, peaceful dialogue [...]. And after the peace talks, we wanted unconditional ceasefire in this country; the third thing we wanted was the coming of an intervention force. ${ }^{56}$

The implementation of peace agreements, including the first post-war elections, is undertaken primarily by state actors and the parties to the conflict (including the armed non-state actors). However, civil non-state actors play significant roles in educating citizens about elections and ensuring the transparency and integrity of elections. In particular, community-based NGOs implement a variety of programs to educate and register voters. Moreover, they act as election observers and provide a critical voice in lending credibility to election results. In Sierra Leone, for example, communitybased NGOs, such as CGG, pushed for the 1996 elections and provided critical social and moral support to the Independent Electoral Commission,

54) Interview, Reverend, Freetown, 25 June 2008.

55) Ibid.

56) Interview with a female program coordinator of the West African Network for Peacebuilding, Monrovia, 2 June 2008. 
which organized the elections against the will of the military government. ${ }^{57}$ Civil non-state actors also serve as a moral voice that exposes violations of peace agreements and those forces that impede the peace process.

The final challenge is post-war reconstruction, which is an essential component of peacebuilding. Given the underlying political and economic roots of civil wars in Africa, post-war reconstruction typically centres on promoting democracy, good governance and economic development. ${ }^{58}$ Post-war reconstruction dovetails with the efforts to promote human development, which is the processes of increasing people's material, social and political wellbeing. ${ }^{59}$ Most of the funding for post-war reconstruction in Sierra Leone, Liberia and Côte d'Ivoire comes from donor countries and international development institutions, most notably UN agencies, the World Bank and the International Monetary Fund (IMF). All three countries have been working with these institutions through the Poverty Reduction Strategy Framework. ${ }^{60}$

Though post-war reconstruction policies and funding are driven by state actors, especially the IMF, the World Bank and former colonial powers, implementation of post-war reconstruction programs at the local level are mostly carried out by civil non-state actors, especially community-based NGOs and international NGOs. ${ }^{61}$ Community-based NGOs receive grants and contracts to implement specific projects especially in the area of education, health, agriculture, and human rights. In Sierra Leone, for example, most of the post-war reconstruction funds given to the National Commission for Social Action (NaCSA) were passed to community-based NGOs in the form of small grants to implement micro level development projects. NaCSA gave out around 600 grants to community-based NGOs. ${ }^{62}$ International NGOs also tend to stay in post-war countries and redirect their programs from relief work to human development. Since the end of

\footnotetext{
57) Robert Press, 'Sierra Leone's Peaceful Resistance to Authoritarian Rule', African Conflict \& Peacebuilding Review, vol. 2, no. 1, 2012, pp. 31-57.

58) Abu Bakarr Bah, 'State Decay: A Conceptual Frame for Failing and Failed States in West Africa', International Journal of Politics, Culture, and Society, vol. 25, no. 1-3, 2012, pp. 71-89; Schümer, New Humanitarianism. Bah, 'The Contours of New Humanitarianism'.

59) UNDP, Human Development Report (1990) (New York: Oxford University Press, 1990).

60) IMF, Sierra Leone: Poverty Reduction Strategy Paper, IMF Country Report No. 05/191 (Washington, D.C.: IMF, June 2005); IMF, Liberia: Poverty Reduction Strategy Paper, IMF Country Report No. 08/219 (Washington, D.C.: IMF, July 2008); IMF, Côte d'voire: Poverty Reduction Strategy Paper, IMF Country Report No. 09/156 (Washington, D.C.: May 2009).

61) Interview, UNDP official, Freetown, 1 July 2008.

62) NaCSA, Reports, http://www.nacsa.gov.sl/report.html, accessed 3 December 2011.
} 
the civil war in Sierra Leone in 2002, for example, Plan International has redirected its programs to support schools in the neediest communities. This fits into the wider focus on education as a way to enhance human development. Plan International's Making Schools Fit for Children program, for example, seeks to provide 'sufficient classroom space and durable child furniture, with plenty of school books and materials, to ensure childfriendly learning environments. ${ }^{63}$ It lobbies for raising the national education budget, increasing the number of qualified teachers, and equal access to education. In Liberia, Mercy Corps has been working with the Liberia Produce Marketing Corporation and local farmers to rehabilitate an 80-acre cocoa farm. The program is designed to increase the cocoa cultivation techniques of farmers and help them 'earn cash by working to clear the overgrowth that accumulated during the war years and strangled the cocoa trees. ${ }^{\prime 64}$ In 2011, the Open Society Initiative in West Africa partnered with the Commission Dialogue, Vérité et Réconciliation to promote a transitional justice program in Côte d'Ivoire. In the same year, it worked with the LIDH to promote a human rights program based on capacity-building and advocacy. ${ }^{65}$ While these are a few examples of the efforts to build peace, they show that civil non-state actors are playing critical roles in the effort to promote human development and thereby consolidate the peace.

\section{Conclusions: Impacts and Limitations of Civil Non-State Actors}

The role of civil non-state actors in peacekeeping and peacebuilding has not received adequate scholarly attention. As this study shows, however, civil non-state actors have played important and delicate roles in peacekeeping operations and the overall peacebuilding process in war-torn West African countries. The three case studies, Sierra Leone, Liberia and Côte d'Ivoire, point to several instances where civil non-state actors have complemented the role of state actors by moving peace processes forward and delivering humanitarian services. This study points to several lessons that

\footnotetext{
63) Plan International, What We Do, http://plan-international.org/where-we-work/africa/ sierra-leone/what-we-do, accessed 9 August 2012.

64) Mercy Corps, Liberia: Strengthening Livelihoods and Building Peaceful Communities, http://www.mercycorps.org/countries/liberia/15083, accessed 2 October 2012.

65) Open Society Initiative in West Africa, Projects Database for Côte d'Ivoire, http://osiwa .org/en/portal/countries/?tpl=15\&tpid=3, accessed 17 September 2012.
} 
are useful for understanding the variety of civil non-state actors and their contributions to peacekeeping and peacebuilding.

The first lesson centers on the fluidity of the category of non-state actors and the need for a more precise conceptualization of the variety of unarmed non-state actors working within the realm of civil society to promote peace and human development in war-torn countries. The extant notions of state actors and non-state actors create a misleading bifurcation in the way we view the various actors involved in peacekeeping and peacebuilding. This bifurcation not only lacks clarity, but also masks the interconnections among state actors and non-state actors working to promote peace and human development in war-torn countries. This study has developed the notion of civil non-state actors to map the variety of civil society organizations promoting peace and human development in war-torn countries. Moreover, the notion of civil non-state actors unmasks the dialectical affinity between state actors and civil society organizations involved in peacekeeping and peacebuilding.

The second lesson shows the critical and complementary role of civil non-state actors in advancing peacekeeping and peacebuilding processes. This positive contribution of civil non-state actors is largely due to their strong values for human security and human development, cultural and social capital, and adaptive capacity. Though civil non-state actors could hardly operate without the security protection offered by formal peacekeeping missions, civil non-state actors play independent roles in the peacekeeping and peacebuilding process. Most importantly, they bring cultural and social capital, which state actors can draw upon when they encounter stalemates or simply do not know how to reach critical actors on the battlefield. The positive contribution of civil non-state actors also results from their belief in the values of human security and human development. These values largely account for the risk they take in reaching people in the most remote areas of war-torn countries and their decisions to stay in those countries for as long as possible. Though civil non-state actors lack military or political mandates, their values give them significant moral influence which sets them apart from state actors, who are often perceived by the warring factions as harboring imperialistic geopolitical agendas. Furthermore, civil non-state actors have a large degree of flexibility in their decision to operate in war-torn countries. This is in part because they do not have to follow strict political and legal procedures in order to do their work, such as getting parliamentary approval or a UN Security Council mandate. 
The third lesson relates to the dependency of civil non-state actors. Though the financial dependency of domestic NGOs on international NGOs and states is widely known, the subtle dependency of civil non-state actors on state actors is masked in their dialectical relation. To some extent, the ability of civil non-state actors to operate in war-torn countries is influenced by the presence of a peacekeeping mission, which would provide minimal levels of security and give security advices. Though civil non-state actors sometimes work in frontlines, even in the absence of a peacekeeping mission, their activities tend to be very minimal in such instances. The deployment of peacekeeping missions gives a sense of reasonable security for civil non-state actors to fully deploy staff and resources. In addition to the physical security dependency, civil non-state actors also depend on state actors to undertake the legal and political actions to support their peacebuilding efforts. In particular, civil non-state actors need states to issue binding resolutions which they can invoke in their work. Moreover, they also need states to take concrete actions, such as arms embargos and threat of prosecution, to hinder the abilities of the warring factions to wage war. In the absence of a peacekeeping mission and the active involvement of state actors, civil non-state actors could only undertake a limited set of activities to help civilians and promote peace.

The final lesson points to the ad hoc and short term nature of many of the activities of civil non-state actors. International peacekeeping and peacebuilding gravitates toward humanitarian and security emergencies. As such, the natural tendency of both state actors and civil non-state actors is to put their resources in areas where there is an urgent humanitarian need. This emergency response approach persists despite repeated efforts to engage in conflict prevention and emergency preparedness. This reality is often reflected in the way international NGOs flood new conflicts areas and how they drawdown from old conflict areas as new humanitarian crises emerge in the international arena. The nature of funding for NGOs, which is largely based on grants and contracts for project implementation, also makes it hard to engage in comprehensive postwar reconstruction efforts. This is compounded by the lack of proper coordination among civil non-state actors. In many cases, projects are duplicated in some areas, while other places are neglected. Moreover, there is hardly sufficient planning for maintenance and continuity after the program period ends. While it is true that most of the work of civil non-state actors is to provide humanitarian relief, it is difficult to engage in effective peacebuilding without making a meaningful impact on human development. 